\title{
Biomolecular Feedback Systems
}

\section{Domitilla Del Vecchio Richard M. Murray \\ MIT Caltech}

Version 1.0a, January 19, 2014

(c) California Institute of Technology

All rights reserved.

This is the electronic edition of Biomolecular Feedback Systems and is available from http://www.cds.caltech.edu/ murray/BFS. Hardcover editions may be purchased from Princeton Univeristy Press, http://press . princeton.edu/titles/10285 .html.

This manuscript is for personal use only and may not be reproduced, in whole or in part, without written consent from the publisher (see http://press.princeton.edu/permissions.html). 


\section{Bibliography}

[1] K. J. Åström and R. M. Murray. Feedback Systems: An Introduction for Scientists and Engineers. Princeton University Press, 2008. Available at http://www.cds.caltech.edu/ murray/amwiki.

[2] B. Alberts, D. Bray, J. Lewis, M. Raff, K. Roberts, and J. D. Watson. The Molecular Biology of the Cell. Garland Science, fifth edition edition, 2008.

[3] R. Algar, T. Ellis, and G.-B. Stan. Modelling the burden caused by gene expression: an in silico investigation into the interactions between synthetic gene circuits and their chassis cell. arXiv:1309.7798, 2013.

[4] U. Alon. An introduction to systems biology. Design principles of biological circuits. Chapman-Hall, 2007.

[5] W. Arber and S. Linn. DNA modification and restriction. Annual Review of Biochemistry, 38:467-500, 1969.

[6] M. R. Atkinson, M. A. Savageau, J. T. Meyers, and A. J. Ninfa. Development of genetic circuitry exhibiting toggle switch or oscillatory behavior in Escherichia coli. Cell, pages 597-607, 2003.

[7] D. W. Austin, M. S. Allen, J. M. McCollum, R. D. Dar, J. R. Wilgus, G. S. Sayler, N. F. Samatova, C. D. Cox, and M. L. Simpson. Gene network shaping of inherent noise spectra. Nature, 2076:608-611, 2006.

[8] D. Baker, G. Church, J. Collins, D. Endy, J. Jacobson, J. Keasling, P. Modrich, C. Smolke, and R. Weiss. ENGINEERING LIFE: Building a FAB for biology. Scientific American, June 2006.

[9] N Barkai and S Leibler. Robustness in simple biochemical networks. Nature, 387(6636):913-7, 1997.

[10] A. Becskei and L. Serrano. Engineering stability in gene networks by autoregulation. Nature, 405:590-593, 2000.

[11] D. Bell-Pedersen, V. M. Cassone, D. J. Earnest, S. S. Golden, P. E. Hardin, T. L. Thomas, and M. J. Zoran. Circadian rhythms from multiple oscillators: lessons from diverse organisms. Nature Reviews Genetics, 6(7):544, 2005.

[12] W. E. Bentley, N. Mirjalili, D. C. Andersen, R. H. Davis, and D. S. Kompala. Plasmid-encoded protein: the principal factor in the "metabolic burden" associated with recombinant bacteria. Biotechnol Bioeng, 35(7):668-81, 1990.

[13] BioNumbers: The database of useful biological numbers. http://bionumbers.org, 2012. 
[14] L Bleris, Z. Xie, D. Glass, A. Adadey, E. Sontag, and Y. Benenson. Synthetic incoherent feedforward circuits show adaptation to the amount of their genetic template. Molecular Systems Biology, 7:519, 2011.

[15] H. Bremer and P. Dennis. Modulation of chemical composition and other parameters of the cell by growth rate. In: Escherichia coli and Salmonella: Cellular and Molecular Biology (edited by Neidhart F. C. et al.), ASM Press, Washington DC, 183:1553-1569, 1996.

[16] H. Bremer, P. P. Dennis, and M. Ehrenberg. Free RNA polymerase and modeling global transcription in Escherichia coli. Biochimie, 85(6):597-609, 2003.

[17] C. I. Byrnes, F. D. Priscoli, and A. Isidori. Output regulation of uncertain nonlinear systems. Birkhauser, 1997.

[18] B. Canton, A. Labno, and D. Endy. Refinement and standardization of synthetic biological parts and devices. Nature Biotechnology, 26(7):787-93, 2008.

[19] M. Chalfie, Y. Tu, G. Euskirchen, W. Ward, and D. Prasher. Green fluorescent protein as a marker for gene expression. Science, 263(5148):802-805, 1994.

[20] A. J. Courey. Mechanisms in Transcriptional Regulation. Wiley-Blackwell, 2008.

[21] R. S. III Cox, M. G. Surette, and M. B. Elowitz. Programming gene expression with combinatorial promoters. Mol Syst Biol, page 3:145, 2007.

[22] D. Del Vecchio, A. J. Ninfa, and E. D. Sontag. Modular cell biology: Retroactivity and insulation. Nature/EMBO Molecular Systems Biology, 4:161, 2008.

[23] L. N. M. Duysens and J. Amesz. Fluorescence spectrophotometry of reduced phosphopyridine nucleotide in intact cells in the near-ultraviolet and visible region. Biochim. Biophys. Acta, 24:19-26, 1957.

[24] H. El-Samad, J. P. Goff, and M. Khammash. Calcium homeostasis and parturient hypocalcemia: An integral feedback perspective. J. Theoret. Biol., 214:17-29, 2002.

[25] S. P. Ellner and J. Guckenheimer. Dynamic Models in Biology. Princeton University Press, Princeton, NJ, 2005.

[26] M. B. Elowitz and S. Leibler. A synthetic oscillatory network of transcriptional regulators. Nature, 403(6767):335-338, 2000.

[27] Michael B Elowitz, Arnold J Levine, Eric D Siggia, and Peter S Swain. Stochastic gene expression in a single cell. Science (New York, NY), 297(5584):1183-1186, 2002.

[28] D. Endy. Foundations for engineering biology. Nature, 438:449-452, 2005.

[29] K M Eveker, D L Gysling, C N Nett, and O P Sharma. Integrated control of rotating stall and surge in high-speed multistage compression systems. Journal of Turbomachinery, 120(3):440-445, 1998.

[30] T.S. Gardner, C.R. Cantor, and J.J. Collins. Construction of the genetic toggle switch in Escherichia Coli. Nature, page 339342, 2000. 
[31] Daniel G. Gibson, John I. Glass, Carole Lartigue, Vladimir N. Noskov, RayYuan Chuang, Mikkel A. Algire, Gwynedd A. Benders, Michael G. Montague, Li Ma, Monzia M. Moodie, Chuck Merryman, Sanjay Vashee, Radha Krishnakumar, Nacyra Assad-Garcia, Cynthia Andrews-Pfannkoch, Evgeniya A. Denisova, Lei Young, Zhi-Qing Qi, Thomas H. Segall-Shapiro, Christopher H. Calvey, Prashanth P. Parmar, Clyde A. Hutchison, Hamilton O. Smith, and J. Craig Venter. Creation of a Bacterial Cell Controlled by a Chemically Synthesized Genome. Science, 329(5987):52-56, 2010.

[32] D. T. Gillespie. Markov Processes: An Introduction For Physical Scientists. Academic Press, 1976.

[33] D. T. Gillespie. Exact stochastic simulation of coupled chemical reactions. Journal of Physical Chemistry, 81(25):2340-2361, 1977.

[34] D. T. Gillespie. The chemical langevin equation. Journal of Chemical Physics, 113(1):297-306, 2000.

[35] L. Goentoro, O. Shoval, M. W. Kirschner, and U. Alon. The incoherent feedforward loop can provide fold-change detection in gene regulation. Molecular Cell, 36:894899, 2009.

[36] A. Goldbeter and D. E. Koshland. An amplified sensitivity arising from covalent modification in biological systems. PNAS, pages 6840-6844, 1981.

[37] J. Greenblatt, J. R. Nodwell, and S. W. Mason. Transcriptional antitermination. Nature, 364(6436):401-406, 1993.

[38] I.L. Grigiriva, N.J. Phleger, V.K. Mutalik, and C.A. Gross. Insights into transcriptional regulation and $\sigma$ competition from an equilibrium model of RNA polymerase binding to DNA. PNAS, 103(14):5332-5337, 2006.

[39] J. Guckenheimer and P. Holmes. Nonlinear Oscillations, Dynamical Systems, and Bifurcations of Vector Fields. Springer, 1983.

[40] S. Hastings, J. Tyson, and D. Webster. Existence of periodic solutions for negative feedback cellular systems. J. of Differential Equations, 25:39-64, 1977.

[41] R. Heinrich, B. G. Neel, and T. A. Rapoport. Mathematical models of protein kinase signal transduction. Molecular Cell, 9:957-970, 2002.

[42] B. Hess, A. Boiteux, and J. Kruger. Cooperation of glycolytic enzymes. Adv. Enzyme Regul, 7:149-167, 1969.

[43] Andreas Hilfinger and Johan Paulsson. Separating intrinsic from extrinsic fluctuations in dynamic biological systems. Proceedings of the National Academy of Sciences, 108(29):12167-12172, 2011.

[44] C. F. Huang and J. E. Ferrell. Ultrasensitivity in the mitogen-activated proteinkinase cascade. Proc. Natl. Acad. Sci., 93(19):10078-10083, 1996.

[45] T. P. Hughes. Elmer Sperry: Inventor and Engineer. John Hopkins University Press, Baltimore, MD, 1993.

[46] A Ishihama. Functional modulation of e. coli rna polymerase. Ann. Rev. Microbiol, 54:499-518, 2000. 
[47] F. Jacob and J. Monod. Genetic regulatory mechanisms in the synthesis of proteins. J. Mol. Biol., 3:318-56, 1961.

[48] S. Jayanthi and D. Del Vecchio. Retroactivity attenuation in bio-molecular systems based on timescale separation. IEEE Trans. Aut. Control, 56:748-761, 2011.

[49] S. Jayanthi, K. Nilgiriwala, and D. Del Vecchio. Retroactivity controls the temporal dynamics of gene transcription. ACS Synthetic Biology, DOI: 10.1021/sb300098w, 2013.

[50] P. Jiang, A. C. Ventura, S. D. Merajver, E. D. Sontag, A. J. Ninfa, and D. Del Vecchio. Load-induced modulation of signal transduction networks. Science Signaling, 4(194):ra67, 2011.

[51] N. G. Van Kampen. Stochastic Processes in Physics and Chemistry. Elsevier, 1992.

[52] A. S. Khalil and J. J. Collins. Synthetic biology: applications come of age. Nature Reviews Genetics, 11(5):367, 2010.

[53] H. K. Khalil. Nonlinear Systems. Macmillan, 1992.

[54] E. Klipp, W. Liebermeister, C. Wierling, A. Kowald, H. Lehrach, and R. Herwig. Systems Biology: A Textbook. Wiley-VCH, 2009.

[55] Stefan Klumpp and Terence Hwa. Growth-rate-dependent partitioning of RNA polymerases in bacteria. PNAS, 105(51):20245-50, 2008.

[56] P. Kundur. Power System Stability and Control. McGraw-Hill, New York, 1993.

[57] M. T. Laub, L. Shapiro, and H. H. McAdams. Systems biology of caulobacter. Annual Review of Genetics, 51:429-441, 2007.

[58] J.-C. Leloup and A. Goldbeter. A molecular explanation for the long-term supression of circadian rhythms by a single light pulse. American Journal of Physiology, 280:1206-1212, 2001.

[59] J. J. Lemke, P. Sanchez-Vazquez, H. L. Burgos, G. Hedberg, W. Ross, and R. L. Gourse. Direct regulation of Escherichia coli ribosomal protein promoters by the transcription factors ppGpp and DksA. PNAS, pages 1-6, 2012.

[60] W. Lohmiller and J. J. E. Slotine. On contraction analysis for non-linear systems. Automatica, 34:683-696, 1998.

[61] H. Madhani. From a to alpha: Yeast as a Model for Cellular Differentiation. CSHL Press, 2007.

[62] J. Mallet-Paret and H.L. Smith. The poincarè-bendixson theorem for monotone cyclic feedback systems. J. of Differential Equations, 2:367-421, 1990.

[63] J. E. Marsden and M. J. Hoffman. Elementary Classical Analysis. Freeman, 2000.

[64] S. Marsigliante, M. G. Elia, B. Di Jeso, S. Greco, A. Muscella, and C. Storelli. Increase of $[\mathrm{ca}(2+)](\mathrm{i})$ via activation of atp receptors in pc-cl3 rat thyroid cell line. Cell. Signal, 14:61-67, 2002.

[65] H. H. McAdams and Arkin A. Stochastic mechanisms in gene expression. PNAS, 94:814-819, 1997. 
[66] C. R. McClung. Plant circadian rhythms. Plant Cell, 18:792-803, 2006.

[67] M. W. McFarland, editor. The Papers of Wilbur and Orville Wright. McGraw-Hill, New York, 1953.

[68] P. Miller and X. J. Wang. Inhibitory control by an integral feedback signal in prefrontal cortex: A model of discrimination between sequential stimuli. PNAS, 103:201-206, 2006.

[69] C. J. Morton-Firth, T. S. Shimizu, and D. Bray. A free-energy-based stochastic simulation of the tar receptor complex. Journal of Molecular Biology, 286(4):105974, 1999.

[70] J. D. Murray. Mathematical Biology, Vols. I and II. Springer-Verlag, New York, 3rd edition, 2004.

[71] C. J. Myers. Engineering Genetic Circuits. Chapman and Hall/CRC Press, 2009.

[72] T. Nagashima, H. Shimodaira, K. Ide, T. Nakakuki, Y. Tani, K. Takahashi, N. Yumoto, and M. Hatakeyama. Quantitative transcriptional control of erbb receptor signaling undergoes graded to biphasic response for cell differentiation. J. Biol. Chem., 282:40454056, 2007.

[73] R. Nesher and E. Cerasi. Modeling phasic insulin release: Immediate and timedependent effects of glucose. Diabetes, 51:53-59, 2002.

[74] H. R. Ossareh, A. C. Ventura, S. D. Merajver, and D. Del Vecchio. Long signaling cascades tend to attenuate retroactivity. Biophysical Journal, 10:1617-1626, 2011.

[75] R. Phillips, J. Kondev, and J. Theriot. Physical Biology of the Cell. Garland Science, 2008.

[76] M. Ptashne. A genetic switch. Blackwell Science, Inc., 1992.

[77] P. E. M. Purnick and R. Weiss. The second wave of synthetic biology: from modules to systems. Nature Reviews Molecular Cell Biology, 10(6):410-422, 2009.

[78] E. K. Pye. Periodicities in intermediary metabolism. Biochronometry, National Acad. Sci., 1971.

[79] L. Qiao, R. B. Nachbar, I. G. Kevrekidis, and S. Y. Shvartsman. Bistability and oscillations in the Huang-Ferrell model of MAPK signaling. PLoS Computational Biology, 3:e184, 2007.

[80] C. V. Rao, J. R. Kirby, and A. P. Arkin. Design and diversity in bacterial chemotaxis: A comparative study in escherichia coli and bacillus subtilis. PLoS Biology, 2(2):239-252, 2004.

[81] H. M. Sauro and B. N. Kholodenko. Quantitative analysis of signaling networks. Progress in Biophysics E Molecular Biology, 86:5-43, 2004.

[82] M. Scott, C. W. Gunderson, E. M. Mateescu, Z. Zhang, and T. Hwa. Interdependence of cell growth and gene expression: Origins and consequences. Science, 330:1099-1202, 2010.

[83] D. E. Seborg, T. F. Edgar, and D. A. Mellichamp. Process Dynamics and Control. Wiley, Hoboken, NJ, 2nd edition, 2004. 
[84] Thomas S Shimizu, Yuhai Tu, and Howard C Berg. A modular gradient-sensing network for chemotaxis in Escherichia coli revealed by responses to time-varying stimuli. Molecular Systems Biology, 6:382, 2010.

[85] O. Shimomura, F. Johnson, and Y. Saiga. Extraction, purification and properties of aequorin, a bioluminescent protein from the luminous hydromedusan, Aequorea. $J$ Cell Comp Physiol, 59(3):223-239, 1962.

[86] O. Shoval, U. Alon, and E. Sontag. Symmetry invariance for adapting biological systems. SIAM J. APPLIED DYNAMICAL SYSTEMS, 10:857886, 2011.

[87] E. D. Sontag. Mathematical Control Theory: Deterministic Finite Dimensional Systems. Springer, New York, 2nd edition, 1998.

[88] E.D. Sontag. Remarks on feedforward circuits, adaptation, and pulse memory. IET Systems Biology, 4:39-51, 2010.

[89] Peter S Swain, Michael B Elowitz, and Eric D Siggia. Intrinsic and extrinsic contributions to stochasticity in gene expression. Proceedings of the National Academy of Sciences of the United States of America, 99(20):12795-12800, 2002.

[90] J. Tsang, J. Zhu, and A. van Oudenaarden. Microrna-mediated feedback and feedforward loops are recurrent network motifs in mammals. Mol. Cell, 26:753-767, 2007.

[91] K. V. Venkatesh, S. Bhartiya, and A. Ruhela. Mulitple feedback loops are key to a robust dynamic performance of tryptophan regulation in Escherichia coli. FEBS Letters, 563:234-240, 2004.

[92] A. C. Ventura, P. Jiang, L. Van Wassenhove, D. Del Vecchio, S. D. Merajver, and A. J. Ninfa. The signaling properties of a covalent modification cycle are altered by a downstream target. Proc. Natl. Acad. Sci. USA, 107(22):10032-10037, 2010.

[93] O. S. Venturelli, H. El-Samad, and R. M. Murray. Synergistic dual positive feedback loops established by molecular sequestration generate robust bimodal response. Proc. of the National Academy of Sciences, 109(48):E3324-33, 2012.

[94] L. Villa-Komaroff, A. Efstratiadis, S. Broome, P. Lomedico, R. Tizard, S. P. Naber, W. L. Chick, and W. Gilbert. A bacterial clone synthesizing proinsulin. Proc. Natl. Acad. Sci. U.S.A., 75(8):372731, 1978.

[95] J. Vind, M. A. Sørensen, M. D. Rasmussen, and S. Pedersen. Synthesis of proteins in escherichia coli is limited by the concentration of free ribosomes. J. Mol. Biol., 231:678-688, 1993.

[96] C. A. Voigt. Genetic parts to program bacteria. Current Opinions in Biotechnology, 17(5):548-557, 2006.

[97] S. Wiggins. Introduction to Applied Nonlinear Dynamical Systems and Chaos. Springer, 2003.

[98] L. Yang and P. A. Iglesias. Positive feedback may cause the biphasic response observed in the chemoattractant-induced response of dictyostelium cells. Systems Control Lett., 55:329 337, 2006. 
[99] T.-M. Yi, Y. Huang, M. I. Simon, and J. C. Doyle. Robust perfect adaptation in bacterial chemotaxis through integral feedback control. Proc. of the National Academy of Sciences, 97(9):4649-4653, 2000.

[100] N. Yildirim and M. C. Mackey. Feedback regulation in the lactose operon: A mathematical modeling study and comparison with experimental data. Biophysical Journal, 84(5):2841-2851, 2003. 